JOURNAL OF MECHANICAL ENGINEERING, MANUFACTURES, MATERIALS AND ENERGY

Doi: $10.31289 /$ jmemme.v5i2.5787

Available online http://ojs.uma.ac.id/index.php/jmemme

\title{
Kinerja Mesin Motor 4 Langkah dengan Bahan Bakar Campuran Bioetanol dan Pertamax
}

\section{Performance of a 4-stroke Motor Engine with a Mixed Fuel of Bioethanol and Pertamax}

\author{
Indra Hermawan ${ }^{1}{ }^{*}$, Muhammad Idris ${ }^{2)}$, Darianto ${ }^{3)}$, M. Yusuf R. Siahaan ${ }^{4)}$ \\ 1,2,3,4 Program Studi Teknik Mesin, Universitas Medan Area, Indonesia \\ Diterima: 04-09-2021 ; Disetujui: 17-12-2021 ; Diterbitkan: 30-12-2021 \\ *Corresponding author: E-mail: indrahermawan@staff.uma.ac.id
}

\begin{abstract}
Abstrak
Ketersediaan bahan bakar fosil sebagai sumber energi semakin terbatas sehingga perlu adanya sumber energi baru sebagai alternatif yang ramah lingkungan, salah satunya adalah bioetanol. Bioetanol adalah salah satu jenis dari biofuel yang bersumber dari materi hidup, biasanya tanaman dengan rumus kimia $\mathrm{C}_{2} \mathrm{H}_{5} \mathrm{OH}$ dan rumus empiris $\mathrm{C}_{2} \mathrm{H}_{5} \mathrm{O}$ dengan angka oktan 108. Salah satu manfaat dari bioetanol untuk campuran bahan bakar dikarenakan nilai oktan yang lebih tinggi, mudah terbakar, panas penguapan dan kandungan oksigen lebih tinggi yang dapat menurunkan suhu silinder sehingga mengurangi emisi NOx dan menghasilkan lebih sedikit $\mathrm{CO}_{2}$. penelitian ini bertujuan mengevaluasi kinerja mesin motor 4 tak dengan membandingkan penggunaan bahan bakar campuran pertamax dengan bioetanol dengan komposisi 25\%, 20\%, dan 0\% bioetanol. Penelitian menggunakan metode eksperimental dimana dilakukan pengumpulan data dan selanjutnya dilakukan pengolahan data dan analisis data. Hasil penelitian diperoleh daya tertinggi sebesar $8,70 \mathrm{~kW}$ pada $25 \%$ bioetanol putaran $6000 \mathrm{rpm}$, diikuti $20 \%$ bioetanol dan $100 \%$ pertamax sebesar 8,60 rpm dengan putaran masing-masing $6500 \mathrm{rpm}$ dan $7000 \mathrm{rpm}$. Torsi tertinggi $25 \%$ bioetanol sebesar 13,80 Nm pada putaran $5500 \mathrm{rpm}$, diikuti 3,10 Nm putaran $5000 \mathrm{rpm}$ 100\% pertamax dan 12,80 Nm pada putaran $5500 \mathrm{rpm}$ bahan bakar 20\% bioetanol. Konsumsi bahan bakar terendah sebesar 0,57 kg/kWh pada putaran $7000 \mathrm{rpm}$ bahan bakar $100 \%$ pertamax, kemudian $0,60 \mathrm{~kg} / \mathrm{kWh}$ bahan bakar $20 \%$ bioetanol pada putaran $6500 \mathrm{rpm}$ dan $0,6 \mathrm{~kg} / \mathrm{kWh}$ bahan bakar $15 \%$ bioetanol pada putaran $6000 \mathrm{rpm}$.
\end{abstract}

Kata Kunci: Bioetanol; Daya; Konsumsi bahan bakar; Pertamax; Torsi

\begin{abstract}
The availability of fossil fuels as an energy source is increasingly limited, so there is a need for new energy sources as environmentally friendly alternatives, one of which is bioethanol. Bioethanol is a type of biofuel sourced from living matter, usually plants with the chemical formula $\mathrm{C}_{2} \mathrm{H}_{5} \mathrm{OH}$ and the empirical formula $\mathrm{C}_{2} \mathrm{H}_{5} \mathrm{O}$ with an octane number of 108. One of the benefits of bioethanol for fuel mixtures is due to the higher octane value, flammability, heat of vaporization and higher oxygen content lowers cylinder temperature thereby reducing NOx emissions and producing less $\mathrm{CO}_{2}$. This study aims to evaluate the performance of a 4 stroke engine by comparing the use of Pertamax and bioethanol mixtures of fuel with a composition of 25\%, 20\%, and $0 \%$ bioethanol. The study used an experimental method where data was collected and then data processing and data analysis were carried out. The results obtained the highest power of $8.70 \mathrm{~kW}$ at 25\% bioethanol at $6000 \mathrm{rpm}$, followed by $20 \%$ bioethanol and $100 \%$ Pertamax at 8.60 rpm with rotations of $6500 \mathrm{rpm}$ and $7000 \mathrm{rpm}$ respectively. The highest torque of 25\% bioethanol is $13.80 \mathrm{Nm}$ at 5500 rpm, followed by $3.10 \mathrm{Nm}$ at $5000 \mathrm{rpm}$ at $100 \%$ pertamax and $12.80 \mathrm{Nm}$ at $5500 \mathrm{rpm}$ with $20 \%$ bioethanol fuel. The lowest fuel consumption is $0.57 \mathrm{~kg} / \mathrm{kWh}$ at $7000 \mathrm{rpm}$ with $100 \%$ pertamax fuel, then $0.60 \mathrm{~kg} / \mathrm{kWh}$ with $20 \%$ bioethanol fuel at $6500 \mathrm{rpm}$ and $0.6 \mathrm{~kg} / \mathrm{kWh}$ with $15 \%$ bioethanol fuel at $6000 \mathrm{rpm}$.
\end{abstract}

Keywords: Bioethanol; Pertamax; Power; Specific fuel consumption; Torque

How to Cite: Hermawan, I.. 2021, Kinerja Mesin Motor 4 Langkah dengan Bahan Bakar Campuran Bioetanol dan Pertamax, JMEMME (Journal of Mechanical Engineering, Manufactures, Materials and Energy), 5 (02): 202-210. 


\section{PENDAHULUAN}

Ketersediaan bahan bakar fosil sebagai sumber energi semakin terbatas sehingga perlu adanya sumber energi baru sebagai alternatif pengganti yang lebih ramah terhadap lingkungan (energi terbarukan). Salah satu sumber energi alternatif yang ramah lingkungan adalah bioetanol. Bioetanol adalah salah satu jenis dari biofuel yang merupakan energi yang terbuat dari materi hidup, biasanya tanaman dengan rumus kimia $\mathrm{C}_{2} \mathrm{H}_{5} \mathrm{OH}$ dan rumus empiris $\mathrm{C}_{2} \mathrm{H}_{5} \mathrm{O}$ dengan angka oktan 108. Bioetanol dibuat dengan teknik fermentasi biomassa seperti umbi-umbian, jagung atau tebu, dan dilanjutkan dengan proses destilasi. Bioetanol dapat digunakan sebagai campuran bahan bakar motor.

Pertamax merupakan salah satu dari jenis bahan bakar yang diproduksi oleh pertamina. Pertamax memiliki angka oktan riset atau Research Octane Number (RON) minimal 92 berstandar internasional. Bahan bakar pertamax disarankan untuk kendaraan yang mempunyai nilai kompresi 9:1 sampai dengan 10:1.

Bahan-bahan alami adalah bahan yang dihasilkan langsung oleh tanaman tanpa melalui proses kimia sebelumnya [1]. Beberapa penelitian telah dikerjakan dalam pemanfaatan bahan-bahan alami sebagai bahan alternatif. Berikut ini adalah usaha pemanfaatan bahan-bahan alami tersebut, antara lain: limbah buah salak dengan limbah air kelapa untuk bahan baku bioethanol [2], tandan kosong kelapa sawit [3], batang pisang [4, 5], bonggol jagung [6], dan kulit kentang [7].

Manfaat dari bioetanol untuk campuran bahan bakar dikarenakan nilai oktan yang lebih tinggi, mudah terbakar, panas penguapan dan kandungan oksigen yang lebih tinggi yang dapat menurunkan suhu silinder sehingga mengurangi emisi NOx dan menghasilkan lebih sedikit $\mathrm{CO}_{2}$ [8]. Bioetanol banyak digunakan sebagai bahan campuran pada pelarut kimia selain bisa juga digunakan sebagai bahan bakar. Sebagai bahan bakar pada motor, bioetanol mempunyai sifat-sifat yang dibutuhkan, seperti nilai oktan yang tinggi, mampu diperbaharui, menghasilkan emisi polutan yang lebih rendah. Sedangkan sifat-sifat yang kurang mendukung sebagai bahan bakar motor Otto adalah nilai kalor yang hanya sekitar 2/3 dibandingkan gasoline, higroskopis dan dapat bercampur air dengan segala perbandingan, sehingga dapat menyebabkan korosi maupun pemisahan [9]. Berdasarkan beberapa penelitian yang telah dilakukan penelitian ini bertujuan untuk mengevaluasi kinerja dari mesin motor 4 tak dengan membandingkan penggunaan bahan bakar campuran pertamax dengan bioetanol dengan komposisi 25\%, 20\%, dan 0\% bioetanol.

Dalam menganalisi suatu kinerja dalam mesin ada beberapa parameter yang dapat diketahui diantaranya torsi (torque), daya (power), konsumsi bahan spesifik $(t)$. Torsi adalah ukuran kemampuan mesin untuk melakukan kerja sedangkan daya adalah tingkat di mana pekerjaan dilakukan [10].

Torsi mesin adalah ukuran kerja yang dilakukan per satuan putaran (radian) poros engkol [11]. Torsi yang diberikan mesin melalui poros penggeraknya biasanya diukur dengan dinamometer. Mesin dipasang pada test bed dan porosnya. Torsi yang diberikan mesin melalui poros penggeraknya biasanya diukur dengan dinamometer. Mesin dipasang pada test bed dan poros tersebut. Rotor digabungkan secara elektromagnetik, 
hidrolik, atau dengan gesekan mekanis ke stator, yang didukung dalam bantalan gesekan rendah. Dudukan bantalan gesek umunya terbuat dari bahan grafit yang cukup tahan terhadap gesekan $[12,13]$. Stator seimbang dengan stasioner rotor. Torsi yang diberikan pada stator dengan putaran rotor diukur dengan menyeimbangkan stator dengan beban, pegas, atau alat pneumatik. Dinamometer biasanya memiliki inersia yang cukup sehingga prosedur ini dengan mesin multisilinder menjumlahkan kontribusi torsi dari setiap silinder, dan mengukur torsi rata-rata waktu. Gambar 1 menggambarkan prinsip pengoperasian dinamometer $[14,15]$.

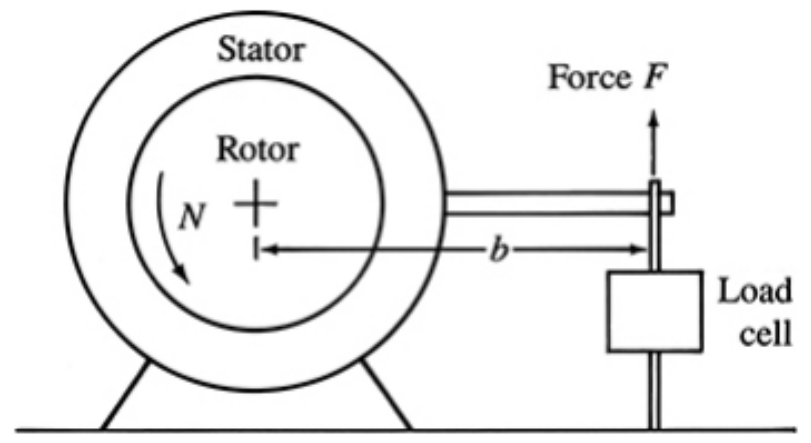

Gambar 1. prinsip pengoperasian dinamometer

Dari gambar 1, persamaan dari torsi dihitung dengan menggunakan persamaan (1).

$$
T=F b
$$

Dimana T adalah Torsi (Nm); F, Gaya penyeimbang (N), dan b adalah jarak lengan (m).

Daya rem adalah laju kerja yang dilakukan. Daya rem adalah keluaran daya mesin, dan diukur dengan dinamometer [16]. Daya yang diberikan oleh mesin dan diserap oleh dinamometer adalah produk dari torsi dan kecepatan sudut. Persamaan dari daya, $\mathrm{P}(\mathrm{kW})$ dihitung dengan menggunakan persamaan $(2)[17,18,19]$.

$$
P=2 \pi N T
$$

Dengan $\mathrm{N}$ adalah kecepatan putaran poros engkol (rpm).

Dalam pengujian mesin, konsumsi bahan bakar diukur sebagai laju aliran yaitu aliran massa per satuan waktu. Parameter yang lain adalah konsumsi bahan bakar spesifik atau specific fuel consumption (sfc), yaitu laju aliran bahan bakar per unit keluaran daya. Ini adalah parameter yang dinormalisasi (yaitu, terlepas dari ukuran mesin), dan mengukur seberapa efisien mesin menggunakan bahan bakar yang dipasok untuk menghasilkan kerja pada kondisi operasi tertentu [20, 21, 22]. Nilai sfc dihitung dengan menggunakan persamaan (3).

$$
s f c=\frac{\dot{m}_{f}}{P}
$$


$\dot{m}_{f}$ adalah laju aliran bahan bakar yang dihitung dengan menggunakan persamaan (4).

$$
\dot{m}_{f}=\frac{V \rho}{t}
$$

Dimana V adalah volume bahan bakar $\left(\mathrm{m}^{3}\right), \rho$ adalah massa jenis bahan bakar $\left(\mathrm{kg} / \mathrm{m}^{3}\right)$ dan t adalah waktu (s)

\section{METODE PENELITIAN}

Penelitian menggunakan metode eksperimental dimana dilakukan pengumpulan data dan selanjutnya dari data yang ada dilakukan perhitungan dengan menggunakan persamaan-persamaan yang diperoleh dari literatur, selanjutnya dilakukan pengolahan data dan analisis data. Pengujian dilakukan dengan menggunakan bahan bakar pertamax murni, pencampuran bahan bakar pertamax dengan bioetanol dengan komposisi bioetanol 25\% dan 20\%.

Adapun data-data alat dan bahan yang digunakan selama melakukan pengujian dan pengumpulan data adalah sebagai berikut: Mesin yang digunakan untuk penelitian ini adalah sepeda motor bensin 4 langkah dengan spesifikasi seperti pada tabel 1, Sedangkan spesifikasi dari bahan bakar yang digunakan seperti terlihat pada tabel 2 .

Tabel 1. Spesifikasi Mesin

\begin{tabular}{ll}
\hline Jenis Mesin & $: 4$ langkah, OHC, pendingin udara \\
Volume langkah & $: 149,2 \mathrm{cc}$ \\
Daya maksimum & $: 10,1 \mathrm{~kW} / 8500 \mathrm{rpm}$ \\
Torsi maksimum & $: 12,8 \mathrm{Nm} / 6500 \mathrm{rpm}$ \\
Kapasitas tangki & $: 12,0 \mathrm{liter}$ \\
Diameter $\times$ langkah & $: 57,3 \times 57,8 \mathrm{~mm}$ \\
Gigi transmisi & $: 5$ kecepatan \\
\hline
\end{tabular}

Tabel 2. Spesifikasi Bahan bakar [23]

\begin{tabular}{lccc}
\hline \multicolumn{1}{c}{ Sifat } & Satuan & Pertamax & Bioetanol \\
\hline Formula (liquid) & - & $\mathrm{C}_{8} \mathrm{H}_{18}$ & $\mathrm{C}_{2} \mathrm{H}_{5} \mathrm{OH}$ \\
Molecular weight & $\mathrm{kg} / \mathrm{kmol}$ & 114,15 & 46,07 \\
Density & $\mathrm{kg} / \mathrm{m}^{3}$ & 765 & 785 \\
Heat of vaporization & $\mathrm{kJ} / \mathrm{kg}$ & 305 & 840 \\
Specific heat (liquid) & $\mathrm{kJ} / \mathrm{kg} \cdot \mathrm{K}$ & 2.4 & 1.7 \\
Specific heat (vapour) & $\mathrm{kJ} / \mathrm{kg} \cdot \mathrm{K}$ & 2.5 & 1.93 \\
Lower heating value & $\mathrm{kJ} / \mathrm{kg}$ & 44.000 & 26.900 \\
Stoichiometric air-fuel ratio by mass & & 14.6 & 9.00 \\
Research octane number & & 92 & 108.6 \\
\hline
\end{tabular}

Pengumpulan data berupa daya dan torsi yang dihasilkan diukur dengan menggunakan alat dynamometer atau dynotest.

\section{HASIL DAN PEMBAHASAN}

Parameter penelitian ini adalah daya dan torsi. Pengujian dilakukan dalam waktu 24 detik dengan jumlah bahan bakar yang terpakai adalah $45 \mathrm{ml}$ (25\% dan 20\% bioetanol) 
dan $43 \mathrm{ml}$ (100\% pertamax). Pengumpulan data dilakukan dalam variasi putaran mesin $1000 \mathrm{rpm}$ sampai dengan $7000 \mathrm{rpm}$, akan diperoleh perbedaan daya dan torsi yang dihasilkan dari masing-masing bahan bakar yang digunakan. Data hasil pengujian terlihat seperti pada tabel 3.

Tabel 3. Data Hasil Pengujian

\begin{tabular}{ccccccc}
\hline \multirow{2}{*}{$\begin{array}{c}\text { Putaran } \\
(\mathrm{rpm})\end{array}$} & \multicolumn{2}{c}{$25 \%$ Bioetanol } & \multicolumn{2}{c}{$20 \%$ Bioetanol } & \multicolumn{2}{c}{ 100\% Pertamax } \\
\cline { 2 - 7 }$(\mathrm{kW})$ & $\begin{array}{c}\text { Torsi } \\
(\mathrm{Nm})\end{array}$ & $\begin{array}{c}\text { Daya } \\
(\mathrm{kW})\end{array}$ & $\begin{array}{c}\text { Torsi } \\
(\mathrm{Nm})\end{array}$ & $\begin{array}{c}\text { Daya } \\
(\mathrm{kW})\end{array}$ & $\begin{array}{c}\text { Torsi } \\
(\mathrm{Nm})\end{array}$ \\
\hline 1.000 & 1,20 & 2,60 & 0,8 & 7,50 & 0,80 & 6,30 \\
1.500 & 1,90 & 3,90 & 1,3 & 7,80 & 1,00 & 6,40 \\
2.000 & 2,50 & 5,20 & 1,3 & 5,90 & 1,20 & 5,50 \\
2.500 & 3,10 & 6,50 & 1,9 & 7,00 & 1,40 & 5,10 \\
3.000 & 3,70 & 7,70 & 3,5 & 10,70 & 3,70 & 11,50 \\
3.500 & 4,30 & 9,00 & 3,8 & 10,10 & 4,70 & 12,60 \\
4.000 & 4,90 & 10,30 & 5,2 & 12,20 & 5,50 & 12,80 \\
4.500 & 5,50 & 11,40 & 5,9 & 12,40 & 6,20 & 13,00 \\
5.000 & 6,90 & 12,90 & 6,2 & 11,60 & 7,00 & 13,10 \\
5.500 & 8,10 & 13,80 & 6,8 & 12,80 & 7,70 & 13,00 \\
6.000 & 8,70 & 13,70 & 8,2 & 12,40 & 8,20 & 12,80 \\
6.500 & 4,30 & 6,30 & 8,6 & 7,80 & 8,40 & 12,20 \\
7.000 & 6,20 & 8,30 & 5,8 & 5,50 & 8,60 & 11,50 \\
\hline
\end{tabular}

Berdasarkan tabel 3 dapat dibuatkan grafik hubungan antara putaran mesin dengan daya untuk masing-masing bahan bakar seperti terlihat pada gambar 2 .

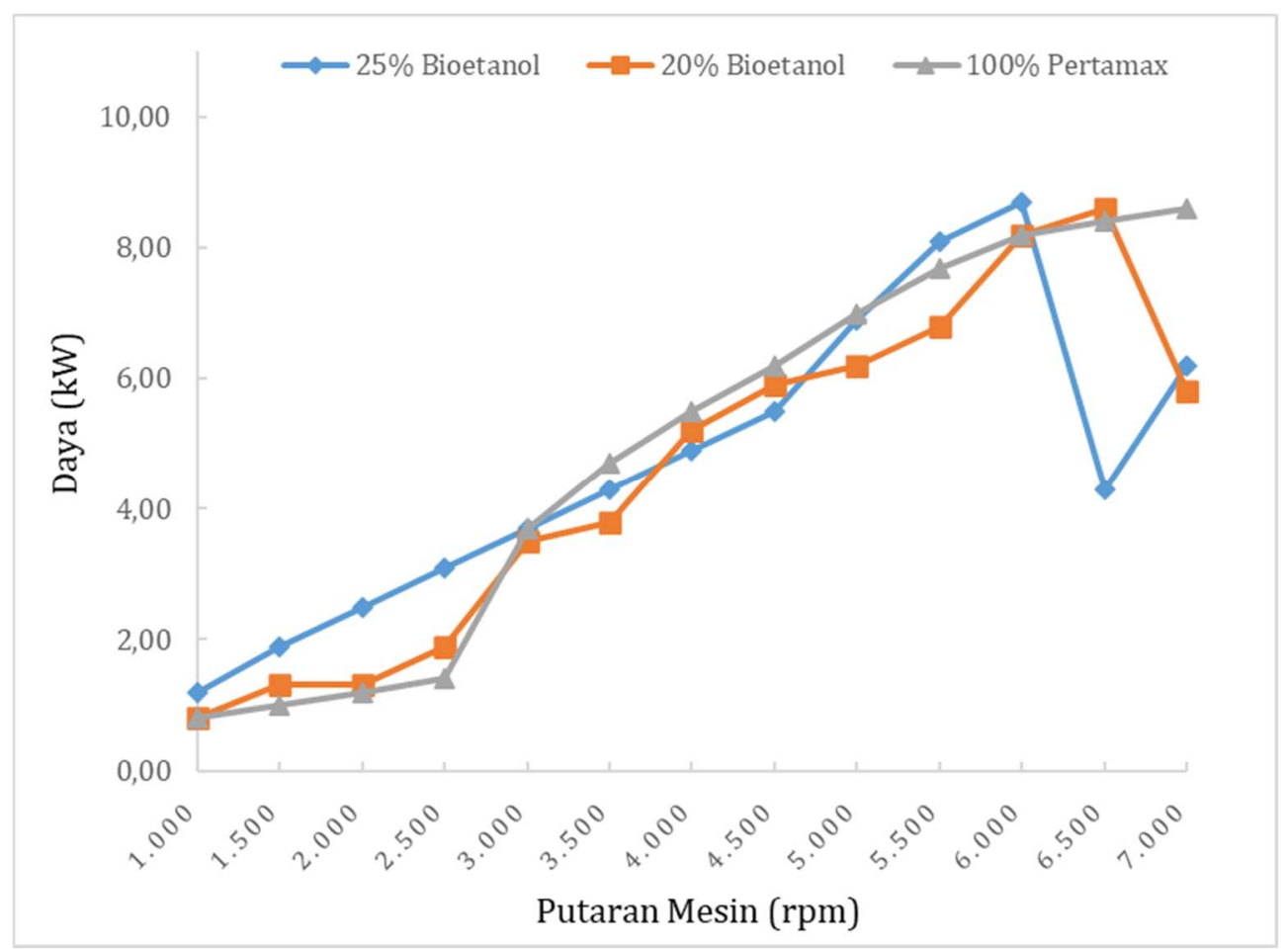

Gambar 2. Hubungan Putaran mesin terhadap Daya 
Pada gambar 2 diperlihatkan bahwa hampir pada semua campuran bioetanol terjadi kenaikan daya seiring dengan terjadinya kenaikan putaran mesin, hanya pada campuran $25 \%$ bioetanol dan $20 \%$ bioetanol terjadi penurunan pada putaran $6500 \mathrm{rpm}$ dan 7000 rpm. Penurunan terjadi disebabkan pada campuran bioetanol terjadi pembakaran kurang sempurna. Daya tertinggi pada campuran bioetaol 25\% berada pada putaran $6000 \mathrm{rpm}$ dengan besar daya $8,70 \mathrm{~kW}$, pada bioetanol $20 \%$ berada pada putaran $6500 \mathrm{rpm}$ dengan besar daya $8,6 \mathrm{~kW}$, dan pada bahan bakar $100 \%$ pertamax daya tertinggi pada putaran $7000 \mathrm{rpm}$ dengan besar daya 8,6 kW. Dari ketika jenis bahan bakar diperlihatkan daya tertinggi adalah pada campuran $25 \%$ bioetanol dengan putaran yang lebih rendah dari yang lain.

Berdasarkan tabel 3 juga dapat dibuatkan grafik hubungan antara putaran mesin dengan torsi untuk masing-masing bahan bakar seperti terlihat pada gambar 3 .

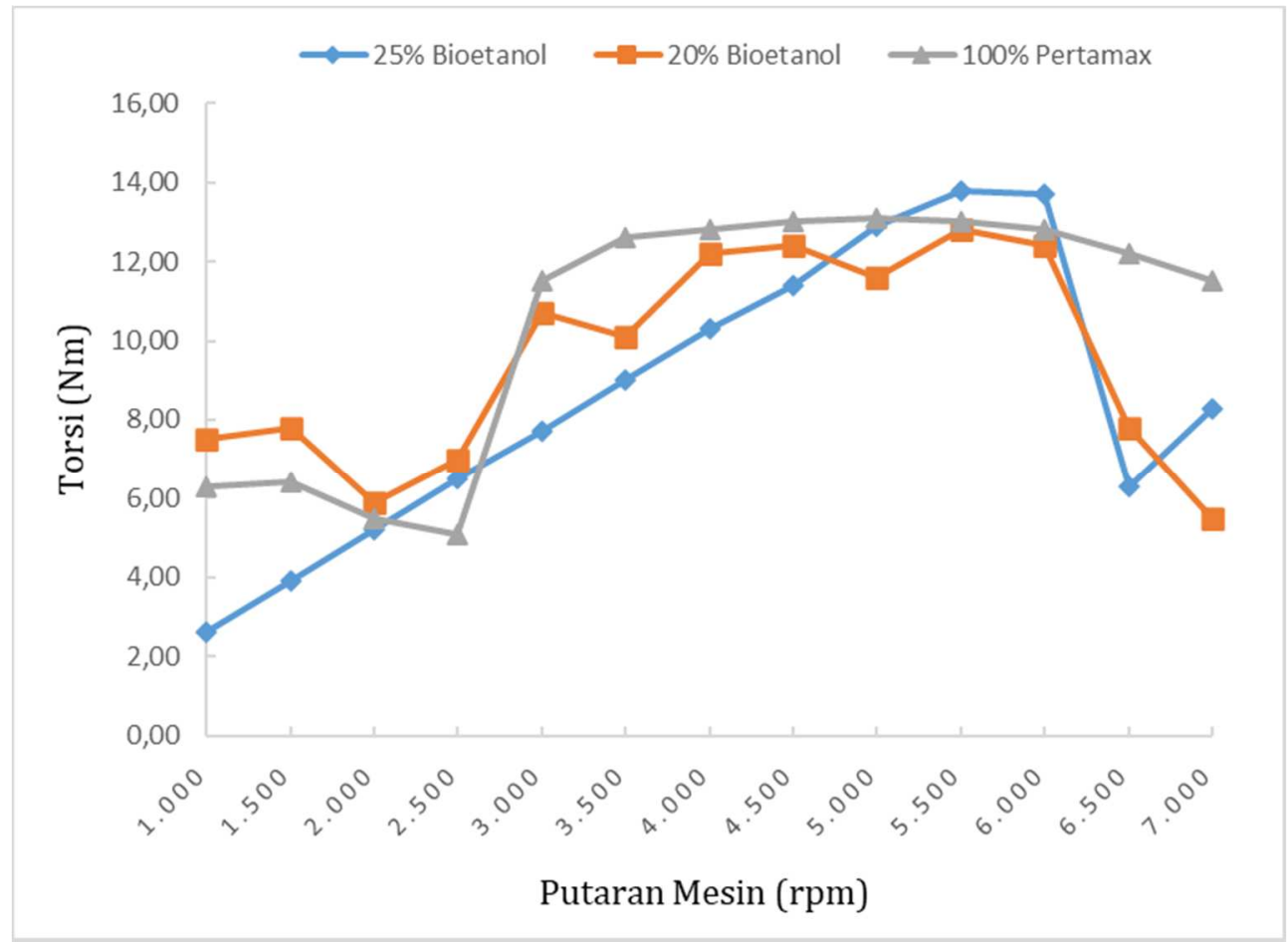

Gambar 3. Hubungan Putaran mesin terhadap Torsi

Pada gambar 3 diperlihatkan bahwa pada campuran bietanol 25\%, torsi tertinggi sebesar 13,80 Nm berada pada puratan $5500 \mathrm{rpm}$. Campuran bioetanol 20\% torsi tertinggi sebesar $12,80 \mathrm{Nm}$ berada pada putaran $5500 \mathrm{rpm}$ dan bahan bakar $100 \%$ pertamax, torsi tertinggi sebesar 13,10 Nm berada pada putaran $5000 \mathrm{rpm}$.

Data hasil perhitungan konsumsi bahan bakar atau specific fuel consumption (sfc) diperlihatkan pada tabel 4 . Berdasarkan tabel 4 dapat dibuatkan grafik hubungan antara putaran mesin dengan nilai sfc untuk masing-masing bahan bakar seperti terlihat pada gambar 4. Pada gambar 4 diperlihatkan bahwa nilai konsumsi bahan bakar terjadi penurunan seiring dengan meningkatnya putaran mesin. Hal ini terjadi disebabkan bahwa pada awal proses pembakaran, pada putaran awal dibutuhkan lebih banyak bahan bakar untuk menggerakkan mesin. Pada bahan bakar capuran 25\% bioetanol, konsumsi bahan bakar teredah pada putaran mesin $6000 \mathrm{rpm}$ dengan nilai sfc sebesar $0,60 \mathrm{~kg} / \mathrm{kWh}$. 
Pada bahan bakar campuran $20 \%$ bioetanol, konsumsi bahan bakar terendah pada putaran mesin $6500 \mathrm{rpm}$ dengan nilai sfc sebesar $0,60 \mathrm{~kg} / \mathrm{kWh}$. Sedangkan pada bahan bakar $100 \%$ pertamax, konsumsi bahan bakar terendah pada putaran 7000 rpm dengan nilai sfc sebesar $0,57 \mathrm{~kg} / \mathrm{kWh}$.

Tabel 4. Data Nilai Konsumsi Bahan Bakar

\begin{tabular}{|c|c|c|c|c|c|c|c|c|c|}
\hline \multirow{2}{*}{$\begin{array}{c}\text { Putaran } \\
\text { Mesin } \\
(\mathrm{rpm})\end{array}$} & \multicolumn{3}{|c|}{$25 \%$ Bioetanol } & \multicolumn{3}{|c|}{$20 \%$ Bioetanol } & \multicolumn{3}{|c|}{$100 \%$ Pertamax } \\
\hline & $\begin{array}{l}\text { Daya } \\
(\mathrm{kW})\end{array}$ & $\begin{array}{l}\text { Torsi } \\
(\mathrm{Nm})\end{array}$ & $\begin{array}{c}\text { SFC } \\
(\mathrm{kg} / \mathrm{kWh})\end{array}$ & $\begin{array}{l}\text { Daya } \\
(\mathrm{kW})\end{array}$ & $\begin{array}{l}\text { Torsi } \\
(\mathrm{Nm})\end{array}$ & $\begin{array}{c}\mathrm{SFC} \\
(\mathrm{kg} / \mathrm{kWh})\end{array}$ & $\begin{array}{l}\text { Daya } \\
(\mathrm{kW})\end{array}$ & $\begin{array}{l}\text { Torsi } \\
(\mathrm{Nm})\end{array}$ & $\begin{array}{c}\mathrm{SFC} \\
\mathrm{kg} / \mathrm{kWh}\end{array}$ \\
\hline 1.000 & 1,20 & 2,60 & 4,33 & 0,8 & 7,50 & 6,49 & 0,80 & 6,30 & 6,17 \\
\hline 1.500 & 1,90 & 3,90 & 2,74 & 1,3 & 7,80 & 3,99 & 1,00 & 6,40 & 4,93 \\
\hline 2.000 & 2,50 & 5,20 & 2,08 & 1,3 & 5,90 & 3,99 & 1,20 & 5,50 & 4,11 \\
\hline 2.500 & 3,10 & 6,50 & 1,68 & 1,9 & 7,00 & 2,73 & 1,40 & 5,10 & 3,52 \\
\hline 3.000 & 3,70 & 7,70 & 1,40 & 3,5 & 10,70 & 1,48 & 3,70 & 11,50 & 1,33 \\
\hline 3.500 & 4,30 & 9,00 & 1,21 & 3,8 & 10,10 & 1,37 & 4,70 & 12,60 & 1,05 \\
\hline 4.000 & 4,90 & 10,30 & 1,06 & 5,2 & 12,20 & 1,00 & 5,50 & 12,80 & 0,90 \\
\hline 4.500 & 5,50 & 11,40 & 0,95 & 5,9 & 12,40 & 0,88 & 6,20 & 13,00 & 0,80 \\
\hline 5.000 & 6,90 & 12,90 & 0,75 & 6,2 & 11,60 & 0,84 & 7,00 & 13,10 & 0,70 \\
\hline 5.500 & 8,10 & 13,80 & 0,64 & 6,8 & 12,80 & 0,76 & 7,70 & 13,00 & 0,64 \\
\hline 6.000 & 8,70 & 13,70 & 0,60 & 8,2 & 12,40 & 0,63 & 8,20 & 12,80 & 0,60 \\
\hline 6.500 & 4,30 & 6,30 & 1,21 & 8,6 & 7,80 & 0,60 & 8,40 & 12,20 & 0,59 \\
\hline 7.000 & 6,20 & 8,30 & 0,84 & 5,8 & 5,50 & 0,89 & 8,60 & 11,50 & 0,57 \\
\hline
\end{tabular}

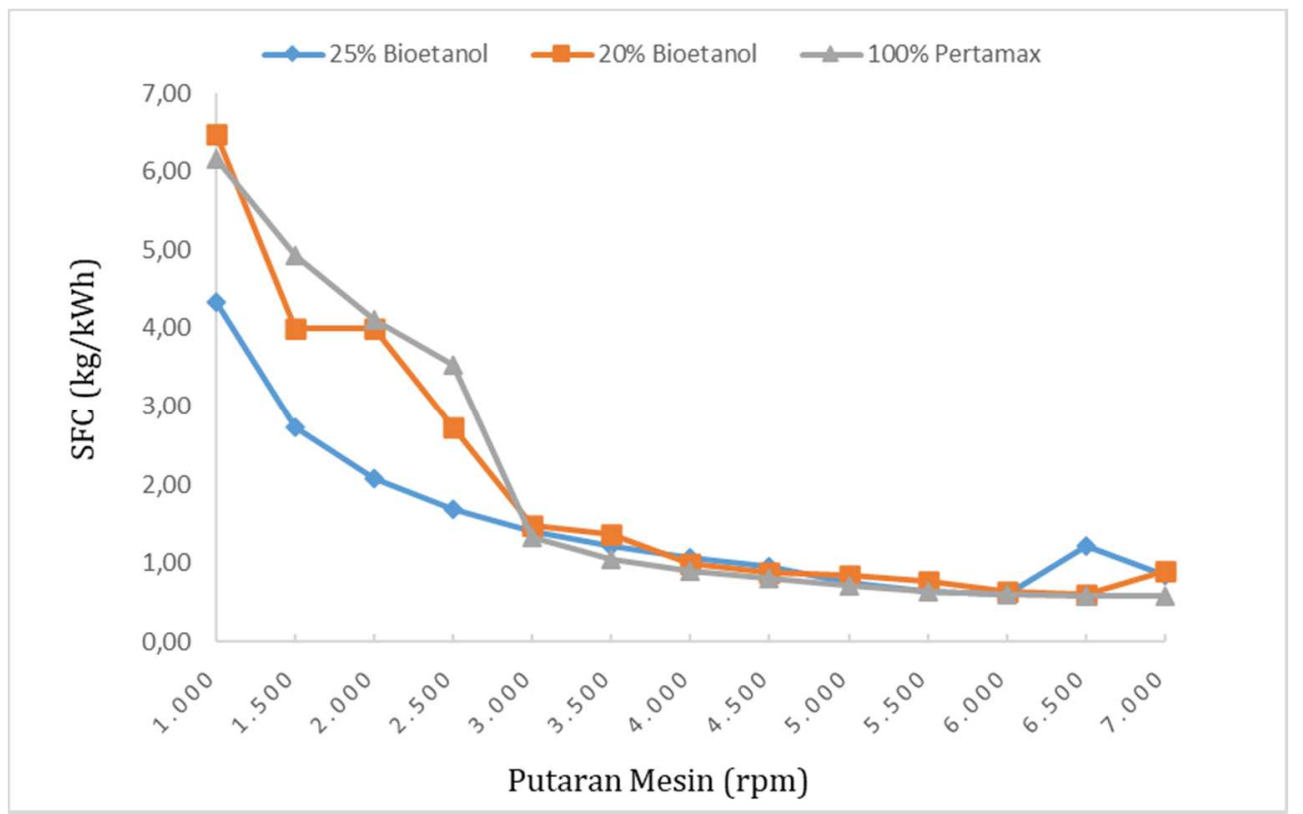

Gambar 4. Hubungan putaran mesin terhadap konsumsi bahan bakar

\section{KESIMPULAN}

Daya tertinggi diperoleh sebesar $8,70 \mathrm{~kW}$ pada campuran $25 \%$ bioetanol pada putaran $6000 \mathrm{rpm}$, diikuti oleh campuran 20\% bioetanol dan 100\% pertamax yaitu sama sebesar 8,60 rpm dengan putaran masing-masing $6500 \mathrm{rpm}$ dan $7000 \mathrm{rpm}$. Torsi tertinggi adalah sebesar campuran $25 \%$ bioetanol sebesar $13,80 \mathrm{Nm}$ pada putaran $5500 \mathrm{rpm}$, 
diikuti oleh 13,10 Nm pada putaran $5000 \mathrm{rpm}$ oleh bahan bakar 100\% pertamax dan 12,80 Nm pada putaran $5500 \mathrm{rpm}$ untuk campuran bahan bakar 20\% bioetanol. Konsumsi bahan bakar terendah adalah sebesar $0,57 \mathrm{~kg} / \mathrm{kWh}$ pada putaran $7000 \mathrm{rpm}$ dengan bahan bakar $100 \%$ pertamax, kemudian $0,60 \mathrm{~kg} / \mathrm{kWh}$ untuk bahan bakar campuran $20 \%$ bioetanol pada putaran $6500 \mathrm{rpm}$ dan $0,6 \mathrm{~kg} / \mathrm{kWh}$ untuk bahan bakar campuran $15 \%$ bioetanol pada putaran $6000 \mathrm{rpm}$

\section{REFERENSI}

[1] A. Siregar , A. Nasution and M. , "Rancangan Media Adsorbsi Zeolit Alam Sebagai Adsorben Emisi Gas Mesin Otomotif," JMEMME (Journal of Mechanical Enggineering, Manufactures, Materials and Energy), vol. 3, no. o1, pp. 64-75, 2019.

[2] M. Idris, "Bioetanol Sebagai Biofuel dari Campuran Limbah Buah Salak dengan Limbah Air Kelapa," Journal of Mechanical Engineering, Manufactures, Materials and Energy, vol. 2, no. 2, pp. 4350, 2018.

[3] A. J. Zulfikar, B. Umroh and M. Y. R. Siahaan, "Penyelidikan Perilaku Mekanik Material Polymeric Foam di Perkuat Serat Tandan Kosong Kelapa Sawit (TKKS) Akibat Beban Statik dan Impak," Journal of Mechanical Enggineering, Manufactures, Materials and Energy, vol. 3, no. o1, pp. 1019, 2019.

[4] A. J. Zulfikar, "The Flexural Strength of Artificial Laminate Composite Boards made from Banana Stems," Budapest International Research in Exact Sciences (BirEx) Journal, vol. 2, no. 3, pp. 334-340, 2020.

[5] A. J. Zulfikar and M. Y. R. Siahaan, "Analisis Signifikansi Roda Skateboard Berbahan Komposit Serbuk Batang Pisang Terhadap Perfoma Kecepatan Dengan Metode Anova," Jurnal Rekayasa Material, Manufaktur dan Energi, vol. 4, no. 2, pp. 83-90, 2021.

[6] R. Anjani, N. Eurika and A. N. Akhmadi, "PENGARUH PENGGUNAAN BATANG DAN BONGGOL JAGUNG TERHADAP KADAR BIOETANOL," Jurnal Unmuh Jember, vol. 3, no. 1, pp. 33-41, 2018.

[7] D. E. PURBA, "PEMBUATAN BIOETANOL DARI KUPASAN KENTANG (Solanum tuberosum L.) DENGAN PROSES FERMENTASI," UNIVERSITAS UDAYANA PRESS, Bukit Jimbaran, 2015.

[8] S.-R. Jhang, Y.-C. Lin, K.-S. Chen and S.-L. Lin, "Evaluation of Fuel Consumption, Pollutant Emissions and Well-towheel GHGs Assessment from a Vehicle Operation Fueled with Bioethanol, Gasoline and Hydrogen," Energy 209, p. 118436, 2020.

[9] S. H. Susilo and A. M. Sabudin, "Pengaruh Campuran Bioetanol-Pertamax 92 terhadap Kinerja Motor Otto," JURNAL ENERGI DAN TEKNOLOGI MANUFAKTUR (JETM), vol. o1, no. o2, pp. 21-26, 2018.

[10] J. B. Heywood, Internal Combustion Engine Fundamentala, New York: McGraw-Hill Education, 2018.

[11] C. R. Ferguson and A. T. Kirkpatrick, Internal Combustion Engines: Applied Thermosciences, United Kingdom: John Wiley \& Sons Ltd, 2016.

[12] I. Iswandi, J. Sahari and A. Sulong, "Effects of Different Particles Sizes of Graphite on the Engineering Properties of Graphites/Polypropylene Composites on Injection Molding Aplication," Key Engineering Materials, vol. 471, no. 1, pp. 109-114, 2011.

[13] I. Iswandi, J. Sahari, A. B. Sulong and T. Husaini, "Critical powder loading and rheological properties of polypropylene/graphite composite feedstock for bipolar plate application," Malaysian Journal of Analytical Sciences, vol. 20, no. 3, pp. 687-696, 2016.

[14] W. p. Aditya and T. Ivan, "Analisa campuran bahan bakar bioetanol dari nira tebu dengan bahan bakar premium terhadap nilai kalor dan unjuk keerja mesin empat langkah," Politeknik Negeri Jember, pp. 30-37, 2017. 
[15] Ramelan, Teori motor bensin dan diesel, Semarang: Jurusan Mesin Universitas Negeri Semarang, 2011.

[16] S. Binjuwair, T. . I. Mohamad, A. Almaleki, A. Alkudsi and I. Alshunaifi, "The Effects of Research Octane Number and Fuel Systems on The Performance and Emissions of a Spark Ignition Engine: A study on Saudi Arabian RON91 and RON95 with Port Injection and Direct Injection Systems," Fuel 158, p. 351-360, 2015.

[17] Cengel A, Yunus and B. Michael A, Thermodinamics and Enginering, Singapore: SI Mc Graw Hiil Book Company, 2006.

[18] Winamo and Joko, "Studi eksperimental pengaruh penambahan bioetanol pada bahan bakar pertamax terhadap unjuk kerja motor bensin," pp. vol.1 hal 33-39, 2011.

[19] S. A. Yudistirani, K. H. Mahmud, F. A. Ummamy and A. I. Ramadhan, "Analisa Perfoma Mesin Motor 4 langkah ${ }^{\prime}$ CCC dengan Menggunakan Campuran Bioetanol-Pertamax," Jurnal Teknologi Universitas Muhammadiyah Jakarta, vol. 11, no. 1, pp. 85-90, 2019.

[20] Jeuland N.M, Montage and X Gautrut, "Pontetiality of ethanol as a fuel for dedicated oil and gas science and technology," IFP, pp. vol,59 no.6:559-570, 2004.

[21] Pratama and M.hafiz, "Uji eksperimental pengaruh penambahan bioetanol pada bahan bakar pertalite terhadap unjuk kerja motor bakar mesin," skripsi, p. Universitas Sumatra Utara, 2015.

[22] C. Wang, S. Zeraati-Rezaei, L. Xiang and H. Xu, "Ethanol Blends in Spark Ignition Engines: RON, Octane-added Value, Cooling Effect, Compression Ratio, and Potential Engine Efficiency Gain," Applied Energy, p. 603-619, 2017.

[23] A. Karthikeyan, D. Venkatesh and T. Ramkumar, "Experimental Investigation on Spark Ignition Engine Using Blends of Bio-ethanol Produced from Citrus Peel Wastes," International Journal of Ambient Energy, 2015. 